\title{
Morphological characterization of fruits, seeds and seedlings of araticum plant (Annona crassiflora Mart - Annonaceae) ${ }^{1}$
}

\author{
Alex Caetano Pimenta ${ }^{2 *}$, Suelen Santos Rego ${ }^{3}$, Katia Christina Zuffellato-Ribas ${ }^{4}$, \\ Antônio Carlos Nogueira ${ }^{3}$, Henrique Soares Koehler ${ }^{3}$
}

\begin{abstract}
Araticum (Annona crassiflora Mart. - Annonaceae) is a species with great ecological importance and potential for fruit production. Its fruits, seeds and seedlings were morphologically described in this article as being the main objective of this study. To describe and illustrate the examples, 100 seeds and 42 fruits were analyzed; the latter being collected in Santo Antônio do Leverger - MT - Brazil, in 2011. To describe the morphology of the seedling, 100 seeds were germinated in two different environments. The araticum plant has a compound, multiple strobiliform, globose-subglobose and fleshy fruit, with average measures of $12.9 \mathrm{~cm}$ length, $13.5 \mathrm{~cm}$ width, $12.7 \mathrm{~cm}$ thickness, weight of $1,187.0 \mathrm{~g}$ and 99.2 seeds per fruit. The seeds are obovoid, hairless, smooth with a bony aspect and a pale brown color; they have an average of $17.7 \mathrm{~mm}$ length, $10.8 \mathrm{~mm}$ width and 8.3 thickness. Epigeous and phanerocotylar germination begins about 148 days after sowing. All morphological data of araticum fruits, seeds and seedlings can be used to recognize the botanical family and, when associated to other features, to recognize the species in the field.
\end{abstract}

Index terms: Annonaceae, araticum, marolo, morphology.

\section{Caracterização morfológica de frutos, sementes e plântulas de araticunzeiro (Annona crassiflora Mart - Annonaceae)}

\begin{abstract}
RESUMO - Objetivou-se com o presente estudo descrever a morfologia de frutos, sementes e plântulas de araticunzeiro (Annona crassiflora Mart. - Annonaceae), uma espécie com alto potencial frutícola e grande valor ecológico. A caracterização das estruturas foi realizada a partir de 42 frutos e de 100 sementes, coletados no município de Santo Antônio do Leverger - MT, em 2011. Para descrever a morfologia da plântula, 100 sementes foram colocadas para germinar, em dois ambientes distintos. $\mathrm{O}$ araticunzeiro apresenta fruto composto, múltiplo estrobiliforme, globoso-subgloboso e carnoso, com médias de 12,9 cm de comprimento, 13,5 cm de largura, 12,7 cm de espessura, massa de 1.187,0 g e de 99,2 sementes por fruto. As sementes são obovoides com tegumento glabro, castanho-claro, opaco, liso e ósseo; possuem em média, 17,7 mm de comprimento, 10,8 $\mathrm{mm}$ de largura e $8,3 \mathrm{~mm}$ de espessura. A germinação é epígea e fanerocotiledonar e se inicia após 148 dias da semeadura. Os aspectos morfológicos do fruto, da semente e da plântula de araticunzeiro podem ser utilizados para o reconhecimento da família botânica e, se associados a outras características, para o reconhecimento da espécie no campo.
\end{abstract}

Termos para indexação: Annonaceae, araticum, marolo, morfologia.

\section{Introduction}

The Annonaceae family comprises 130 genera and 2,200 species, distributed predominantly tropically. In Brazil there are 33 genera that are home to about 250 species (Souza and Lorenzi, 2005), including wild and cultivated, many of which have high-quality fruits, especially those belonging to the genus Annona (Joly, 1998).

${ }^{1}$ Submitted on 6/20/2013. Accepted for publication on 8/19/2013.

${ }^{2}$ Instituto Federal de Educação, Ciência e Tecnologia de Mato Grosso, 78106-960 - Santo Antonio do Leverger, MT, Brasil.

${ }^{3}$ Departamento de Ciências Florestais, UFPR, 80210-170 - Curitiba, PR, Brasil.
The araticum tree (Annona crassiflora Mart. Annonaceae), also known as Marolo or Araticum do cerrado, is native to the Brazilian Cerrado, in the states of São Paulo, Mato Grosso do Sul, Mato Grosso, Minas Gerais, Goiás, Bahia and Tocantins (Lorenzi, 2002). It is an arboreal plant, which can reach up to $8 \mathrm{~m}$ of height (Silva et al., 2001; Lorenzi, 2002), whose winding stem, $20-30 \mathrm{~cm}$ in diameter, is covered with a rough and very thick bark, which provides resistance to

${ }^{4}$ Departamento de Botânica, UFPR, Caixa Postal 19031, CEP 81531-970 Curitiba, PR, Brasil.

*Corresponding author <profpimenta@hotmail.com> 
the action of fire (Lorenzi, 2002). The araticum tree leaves are alternate, distichous, simple and without stipules (Souza and Lorenzi, 2005; Lobão et al., 2005) and the flowers are isolated, axillary, actinomorphic with three sepals, six petals and numerous stamens and carpels (Lobão et al., 2005). The fruit is a multiple strobiliform type, glabrous, of subglobose form, composed of numerous small fruits that mostly contains a single seed. The tubercular and papillose epicarp staining is green when immature and greenish brown when mature (Lima-Brito et al., 2006).

The araticum tree is one of the most frequent species in the Cerrado biome, exploited by the local population for food and medicinal use. By presenting appreciable aroma, flavor and digestibility, the pulp of its fruit is consumed fresh or processed for the production of juices, liqueurs, ice cream and jellies (Telles et al., 2003). Besides the organoleptic characteristics, the fruit has a high nutritional value, with significant levels of lipids, fibers, calories, magnesium, phosphorus and antioxidants (Damiani et al., 2011). Furthermore, the araticum tree can also have an allelopathic effect on other species, inhibiting germination and/or seedling development of Marandu grass (Brachiaria brizantha Stapf.) and of soybean (Inoue et al., 2009), plus an insecticide effect, which enables its use in controlling the bug vector of dengue fever (Aedes aegypti L.) (Omena et al., 2007) and of brown stink bug (Euschistus heros Fabr.) (Oliveira and Pereira, 2009).

The study of fruits, seeds and seedlings, besides contributing to the knowledge of the species, generates information necessary for taxonomic and phylogenetic purposes, adding to the traditional analyzes of vegetative and floral organs (Oliveira, 2001). Thus, morphological studies assist in interpreting laboratory tests and allow the identification of botanical species, constituting an important tool to recognize it in the seed banks in the soil and in seedling stage in forest formations (Melo et al., 2004). The knowledge of the morphology of native plants is of great value to understanding the behavior of the species in relation to the mechanisms of dispersal, succession, natural regeneration and conservation (Melo et al., 2004; Cosmo et al., 2010).

The use of morphological characters with taxonomic purpose is especially important for Annonaceae, considering that this family is one of the most uniform, both in terms of anatomical and structural points of views, of habit and habitat, with a combination of striking and peculiar characters (Barroso et al., 1978). This information is confirmed by the morphology of the ruminated seed and tiny embryo, which constitutes is a good character of identification at the family level, although the identification of some genera is hampered by the lack of data regarding the fruits and they are underrepresented in spaces for collection of information about fruit trees and fruits and herbaria (Barroso et al., 1999).

The morphology of fruits, seeds and seedlings of the araticum tree was studied by Lima-Brito et al. (2006), from a native population in the Brazilian State of Bahia. However, similar studies are necessary with populations of different regions, because phenotypic variations in response to the heterogeneity are expected in the cerrado plants, as reported by Rocha Filho and Lomônaco (2006).

Accordingly, the aim of the present study was to describe and illustrate the morphology of fruits, seeds and seedlings of Annona crassiflora Mart.

\section{Materials and Methods}

Fruit collection - fruits were collected from February to March 2011, from mother plants selected in the araticum tree native population belonging to the Cascata do Andorinha farm, located in the geographic coordinates $15^{\circ} 50^{\prime} \mathrm{S}$ and $55^{\circ} 21^{\prime} \mathrm{W}$, at $770 \mathrm{~m}$ of altitude, in the municipality of Santo Antônio do Leverger (MT). For species identification, samples were collected from the plant material and compared with the exsiccated specimen registered under number 23,134, deposited in Herbário Central at Universidade Federal de Mato Grosso, in Cuiabá (MT). Forty two fruits were collected immediately after their dispersion from 17 mother plants, being collected randomly, in order of maturity. After collection, the fruits were packed in polypropylene trays $(50 \times 31 \times 8 \mathrm{~cm})$ and transported to Instituto Federal de Educação, Ciência e Tecnologia de Mato Grosso, Campus São Vicente (IFMT Campus São Vicente), located in the municipality of Santo Antônio do Leverger (MT), where the assessments related to the morphological characterization of the fruits were conducted.

Morphological characterization of the fruits - to determine the length, width and thickness of the fruit was used a digital caliper graduated from $30 \mathrm{~cm}$ and accuracy of $0.001 \mathrm{~cm}$, positioned at the apex at the scar of the stalk to length, the width being the largest transverse axis and the thickness the smallest transverse axis. To measure the mass of the fruit, was used a digital scale with a capacity of six kilograms (13 pounds), accurate to $0.002 \mathrm{~g}$ and the number of seeds per fruit was verified after manual pulping. In addition to the measurable variables, were observed in the fruit: type, shape, texture, surface and color, performing transverse and longitudinal sections in the pericarp for observation of detail when necessary.

Seed processing and samples preparation: after pulping 
the fruits, the seeds were washed in running water until complete removal of the pulp and dried in the shade for 48 hours on paper towel. The seeds with malformation, cracks or holes in the seed coat were removed. Whole seeds were packed in "Kraft" paper bag and transported to Laboratório de Análise e Tecnologia de Sementes of the Departamento de Fitotecnia e Fitossanitarismo of the Universidade Federal do Paraná, in Curitiba (PR). Subsequently, the average sample was homogenized and divided into duplicate sample and working sample, using a centrifugal divider. Both samples were kept in a dry chamber at a temperature of $17 \pm 2{ }^{\circ} \mathrm{C}$ and relative humidity of $60-70 \%$, until being used.

Morphological characterization of the seeds: in April 2011 were randomly drawn 100 seeds from the working sample for morphological description and illustration. The dimensions of length, width and thickness were measured with a digital caliper graduated $20 \mathrm{~cm}$ and accuracy of $0.001 \mathrm{~g}$.

In seeds were externally observed: shape, color, texture, consistency, presence of aryl and positions of hilum and micropyle. For internal descriptions regarding the presence of endosperm, type, position and shape of the embryo and the position of the radicle-hypocotyl axis, transverse and longitudinal sections were performed in the seed, using a scalpel blade and observation in stereoscopic microscopic (Abreu et al., 2005; Rego et al., 2010). For better observation of the embryo, 60 seeds were imbibed in distilled water for 24 hours at $25^{\circ} \mathrm{C}$, followed by removal of the integument and longitudinal section parallel to the embryonic axis. Subsequently, was performed staining of the embryos on filter paper moistened in 2.5 times the mass of the paper, with a tetrazolium solution $(2,3,5$ triphenyl tetrazolium chloride) $0.5 \%$ for six hours in an incubator with a temperature of $25^{\circ} \mathrm{C}$.

Morphological characterization of the seedlings: 100 seeds were put to germinate in polypropylene boxes containing vermiculite as substrate, moistened in its field capacity. The boxes were maintained in an incubator without controlling environmental conditions. 100 seeds were also sown on paper towel roll, moistened with water at a ratio of 2.5 times its dry weight. The rolls were kept in an Mangelsdorf type incubator, at $25{ }^{\circ} \mathrm{C}$ and constant light of $110 \mathrm{Lx}$. The phases between the swelling of the endosperm and the full development of protophylls were observed. To characterize the seedling were observed type, shape, color and hairiness of the root and of the hypocotyl and consistency, texture, shape, color, veining and type of maple, apex and base of the protophylls. The technological procedures for the study of the morphology of the fruit, seed and seedling were based on the work by Barroso et al. (1999).

Statistical procedures-the data of the quantitative variables were electronically tabulated and analyzed, determining the minimum, average and maximum values with their respective standard deviation and coefficient of variation.

\section{Results and Discussion}

Morphological characterization of the fruits - the araticum tree fruits (Figure 1) are of the composite type, multiple strobiliform, according to the classification from Barroso et al. (1999), globose to subglobose in shape and with a fleshy consistency. 33-152 seeds per fruit were found. The fruits are, on average, $12.9 \mathrm{~cm}$ long, $13.5 \mathrm{~cm}$ wide, $12.7 \mathrm{~cm}$ thick and $1,187 \mathrm{~g}(0.00261688705$ pounds) weight (Table 1$)$. The fruits are formed by many monospermic small fruits (Figure 1C), but occasionally in some were found two or more seeds, which had a modified shape over the species standard. The fruits are composed by mesocarp and endocarp, fleshy consistency, sincarpic, coalescing, non drupoid and arranged on a fleshy and taper receptacle (stalk) (Figure 1D). The epicarp is glabrous, tubercular and papillose (Figures 1A, 1B, 1C, 1D) and staining is green when immature and greenish brown when mature.

The morphological information of the fruit of the araticum tree agree with the description of Lima-Brito et al., (2006), in a study of the morphology of fruits of the Annonaceae family, including Annona crassiflora.

Table 1. Length, width, thickness, fresh mass and number of

seeds/fruit of fruits of Annona crassiflora.

\begin{tabular}{crrrcr}
\hline Variable & Minimum & Average & Maximum & Standard deviation & Coefficient of variation $(\%)$ \\
\hline Length $(\mathrm{cm})$ & 9.5 & 12.9 & 18.0 & 1.9 & 14.4 \\
Width $(\mathrm{cm})$ & 10.5 & 13.5 & 17.8 & 1.5 & 10.8 \\
Thickness $(\mathrm{cm})$ & 9.9 & 12.7 & 16.6 & 1.5 & 11.6 \\
Fresh mass $(\mathrm{g})$ & 515.0 & $1,187.0$ & $2,040.0$ & 365.9 & 30.8 \\
Number of seeds/fruit & 33.0 & 99.2 & 152.0 & 33.4 & 33.7 \\
\hline
\end{tabular}

Journal of Seed Science, v.35, n.4, p.524-531, 2013 


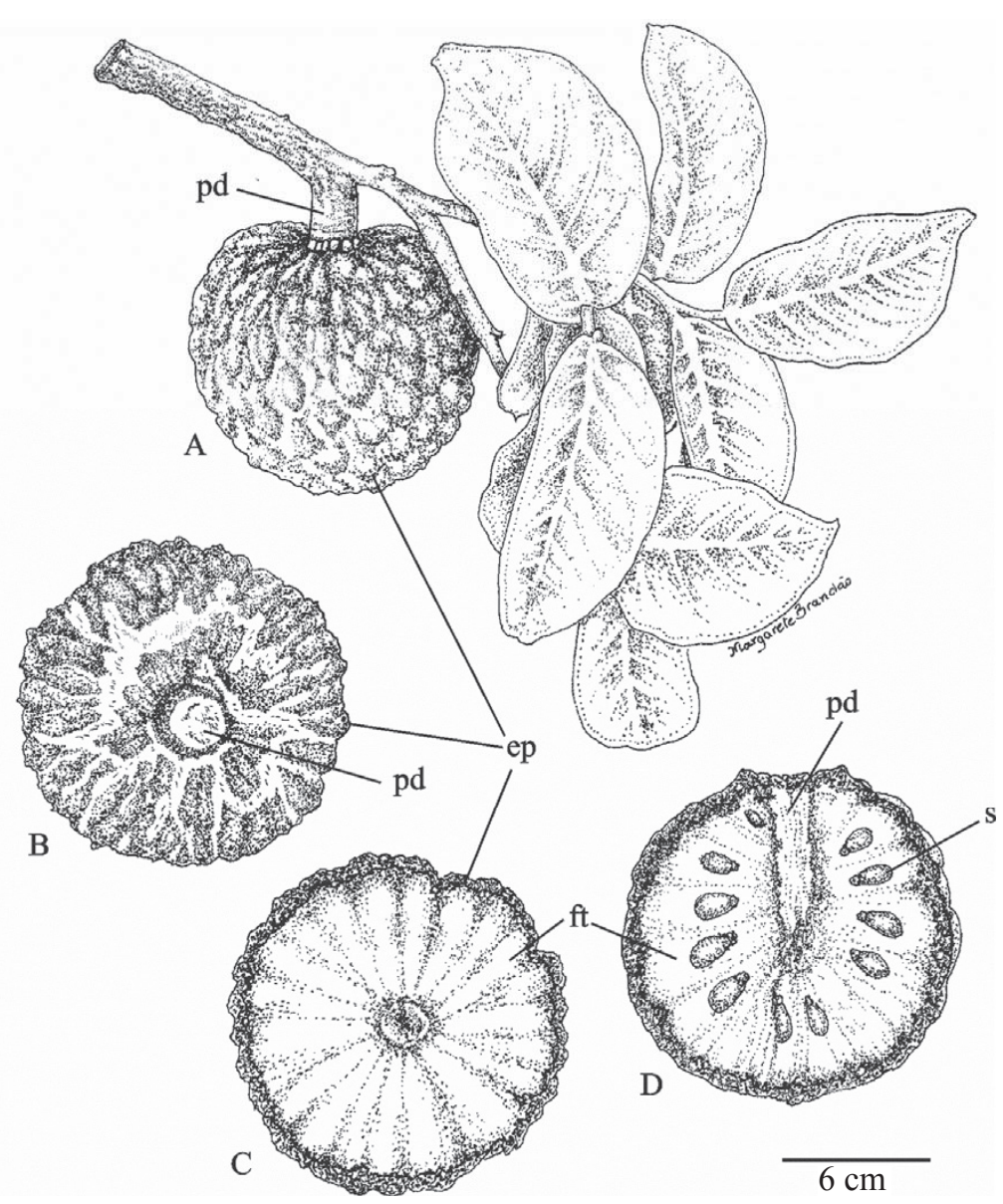

Figure 1. Fruit of Annona crassiflora. (A) branch with fruit and external appearance in lateral view; (B) external appearance in basal view; (C) internal appearance in cross-sectional view; (D) internal appearance in longitudinal view. pd: stalk; ep: epicarp; ft: small fruit; s: seed.

The fruit mass of the araticum tree obtained in this work is comprised within the range of 0.5 to $4.5 \mathrm{~kg}$ per fruit mentioned by Silva et al. (2001), however, with average mass higher than those found by Lima-Brito et al. (2006) found an average of $836.3 \mathrm{~g}$ in fruits of the araticum tree collected in the Brazilian state of Bahia. The values for fruit mass found in the present work, as well as those cited by other authors, emphasize the importance of the species, as a fruit plant, because the size of the fruit greatly surpasses other species of the genus that are already grown for this purpose and whose fruits have wide acceptance in consumer markets, particularly in their centers of origin. Among them it is possible to mention sugar-apples (Annona squamosa L.) and custard-apple (Annona cherimola Mill. x Annona squamosa L.), with average masses of $231 \mathrm{~g}$ (Lima-Brito et al., 2006) and $275 \mathrm{~g}$ to $368 \mathrm{~g}$ (Neves and Yuhara, 2003), respectively. Regarding the size of the fruit, the araticum tree can be compared to Brazilian pawpaw (soursop, prickly custard apple, Soursapi) (Annona muricata L.), which has a mass of approximately $1 \mathrm{~kg}$ (Lima-Brito et al., 2006) and with wild sugar apple or aratiku (Rollinia mucosa (Jacq.) Baill.) which produces fruits of mass equal to $1.3 \mathrm{~kg}$ (Lorenzi, 2002).

Morphological characterization of the seeds - the seeds of the araticum tree are obovoid (Figure 2A) and in average are $17.7 \mathrm{~mm}$ long, $10.8 \mathrm{~mm}$ wide and $8.3 \mathrm{~mm}$ thick (Table 2). The integument is glabrous, light brown in color, opaque, with a smooth texture and a bony consistency. The tegmen is comprised of fibrous layers that fall within the endosperm resulting in ruminations (Figure 2E), as described by (Lima-Brito et al., 2006). It was observed that after seed drying, the tegmen fibers detach and the assembly formed by the endosperm and embryo becomes loose within the integument. The araticum tree seeds have basal aryl of rough surface and irregular and conspicuous boundary (Figures 2A, 2B, 2C and 2D) arranged around the hilum and the micropyle. The hilum is basal, miniature and irregularly shaped between circular and oval (Figure 2C) and closed by a fold of buffer, corroborating the information 
cited by Barroso et. al. (1999) for the Annonaceae family. After removal of the aryl it was possible to see the micropyle (Figure 2D), forth below and in continuity with the hilum. The endosperm is ruminated, thick, abundant (Figure 2F) and whitish-yellow in color. The embryo is basal and crude, approximately $2 \mathrm{~mm}$ long (Figures $2 \mathrm{~F}, 2 \mathrm{G}$ and $2 \mathrm{H}$ ), hyaline and gelatinous. It was observed in the embryonic axis the region of the radicle and cotyledons (Figure $2 \mathrm{H}$ ), although for most seeds, these structures had not fully differentiated, similar to the observations by Silva et al. (2007).

Table 2. Length, width and thickness of seeds of Annona crassiflora.

\begin{tabular}{cccccc}
\hline Variable & Minimum & Average & Maximum & Standard deviation & Coefficient of variation $(\%)$ \\
\hline Length $(\mathrm{mm})$ & 13.4 & 17.7 & 22.7 & 2.3 & 13.1 \\
Width $(\mathrm{mm})$ & 9.0 & 10.8 & 13.6 & 0.9 & 8.7 \\
Thickness $(\mathrm{mm})$ & 6.4 & 8.3 & 11.2 & 0.8 & 9.7 \\
\hline
\end{tabular}

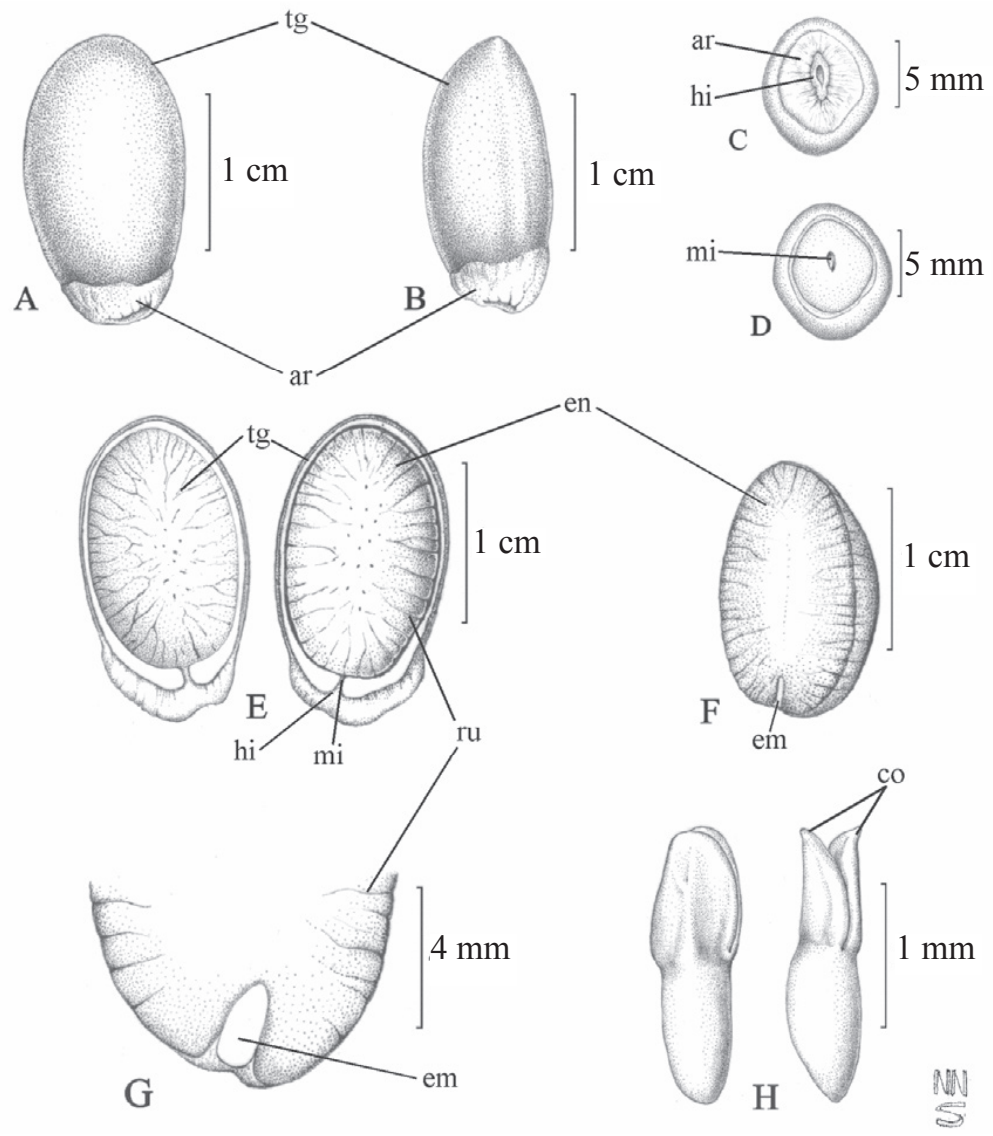

Figure 2. Seed of Annona crassiflora. (A) lateral view; (B) dorsal view; (C) basal view; (D) basal view without the aryl; (E) integument and endosperm; (F) longitudinal section of the endosperm; ( $\mathrm{G}$ and $\mathrm{H}$ ) embryo. tg: integument; ar: aryl; mi: micropyle; hi: hilum; en: endosperm; ru: rumination; em: embryo; co: cotyledon.

The morphological characteristics of the seed found in this experiment are equivalent to the information about the species cited by Lima-Brito et al. (2006) and Silva et al. (2007).

Among the features described for the seed, the embryo size and ruminations are of fundamental importance for the botanical identification of individuals at family level because they are specific conditions of Annonaceae (Barroso et al., 1999).
According to Barroso et al. (1999), the embryo is small because it develops very late after the seed is almost entirely formed, which becomes an ecological mechanism for survival of the species, either for the time required for germination (Silva et al., 2007), which enables the new individual a more favorable environment for their development and/or the formation of persistent seed banks in the soil (Cavalcante et al., 2007). 
Morphological characterization of the seedlings - after 148 days of sowing was observed a longitudinal rupture of the integument caused by swelling of the endosperm (Figure $3 \mathrm{~A}$ ) and primary root protrusion (Figure $3 \mathrm{~B}$ ), followed by elongation of the primary root and hypocotyl (Figure 3C), secondary root formation (Figure 3D), expansion of cotyledons parallel to the development of protophylls (Figure 3E) and ending with the seedling formed (Figure 3F), in approximately 190 days after sowing. The long period required for seed germination and seedling development of this experiment is due to the morphophysiological numbness peculiar to the species (Silva et al., 2007) and most likely to the low ambient temperatures recorded during the test.

The germination of the araticum tree is epigeal and phanerocotylar, which starts by primary root protrusion in the region of the micropyle (Figure $3 \mathrm{~B}$ ). The primary root is axial, cylindrical, of pale cream-white color, glabrous and long, with secondary roots originating from the base of the collect, which resemble the main root, but thinner and shorter; the hypocotyl is fleshy, thick, glabrous and white in color and/or slightly pink, which holds at its apex the endosperm and other overhead structures still surrounded by the integument (Figure 3D).

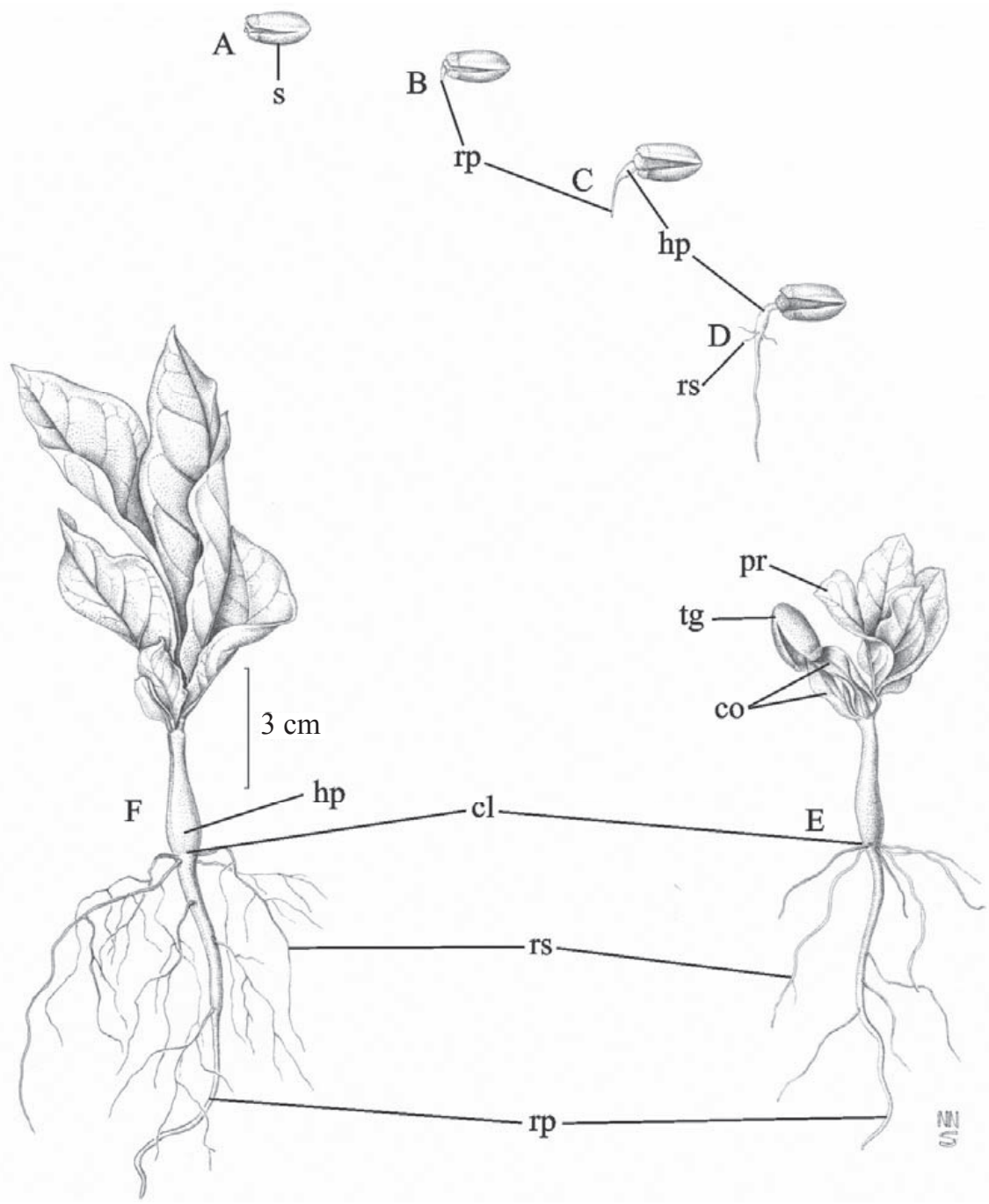

Figure 3. Germination of Annona crassiflora. (A - D) initial phase; (E - F) details of the seedling. s: seed; rp: primary root; hp: hypocotyl; rs: secondary root; pr: protophyll; tg: integument; co: cotyledons; cl: collect.

Consumption of the araticum tree seeds reserves is slow, and even after the expansion of the cotyledon leaves and the development of the first leaves (protophylls), it is possible to observe residues of the endosperm and the integument still adhering to the seedling (Figure 3E). When the seedlings are formed it is observed a complex root system formed by the primary and thick root close to the collect and tapering towards the apex, and from it and from the base of the collect emerge secondary roots, which branch 
out and complete the root system (Figure 3F). The hypocotyl is thick, with a thicker base with respect to the apex, in which the fully developed cotyledons and protophylls are observed. The cotyledons and protophylls are petiolate and innervated, and the protophylls and adult leaves have similar characteristics as the limbus and the ribs. Leaves are simple, elliptic, glabrous of obtuse to slightly acute apex and wedge-shaped base.

\section{Conclusions}

The araticum plant has a compound, multiple strobiliform, globose-subglobose and fleshy fruit, with average measures of $12.9 \mathrm{~cm}$ length, $13.5 \mathrm{~cm}$ width, $12.7 \mathrm{~cm}$ thickness, weight of $1,187.0 \mathrm{~g}$ and 99.2 seeds per fruit. The seeds are obovoid, hairless, smooth with a bony aspect and a pale brown color; they have an average of $17.7 \mathrm{~mm}$ length, $10.8 \mathrm{~mm}$ width and 8.3 thickness.

Epigeous and phanerocotylar germination begins about 148 days after sowing.

All morphological data of the araticum fruits, seeds and seedlings can be used to recognize the botanical family and, when associated to other features, to recognize the species in the field, provided that associated with other characteristics, such as those observed in leaves and flowers.

\section{References}

ABREU, D. C. A.; KUNIYOSHI, Y. S.; MEDEIROS, A. C. S.; NOGUEIRA, A. C. Caracterização morfológica de frutos e sementes de cataia (Drimys brasiliensis Miers. - Winteraceae). Revista Brasileira de Sementes, v. 27, n. 2, p. 67-74, 2005. http://www.scielo.br/pdf/rbs/v27n2/a10v27n2.pdf

BARROSO, G. M.; GUIMARÃES, E. F.; ICHASO, C. L. F.; COSTA, C. G.; PEIXOTO, A. L. Sistemática de angiospermas do Brasil. v. 1. São Paulo: EDUSP, 1978. 309 p.

BARROSO, G. M.; MORIM, M. P.; PEIXOTO, A. L.; ICHASO, C. L. F. Frutos e sementes: morfologia aplicada à sistemática de dicotiledôneas. Viçosa - MG: UFV, 1999. 443 p.

CAVALCANTE, T. R. M.; NAVES, R. V.; BRAGA FILHO, J. R.; SILVA, L. B. Influência de substratos e do armazenamento de sementes sobre a emergência e crescimento de plântulas de araticum (Annonaceae). Bioscience Journal, v. 23, n. 4, p. 11-20, 2007. http://www.seer.ufu.br/index.php/ biosciencejournal/article/view/6909/4575

COSMO, N. L.; NOGUEIRA, A. C.; LIMA, J. G.; KUNIYSHI, Y. S. Morfologia de fruto, semente e plântula de Sebastiania commersoniana, euphorbiaceae. Floresta, v. 40, n. 2, p. 419-428, 2010. http://ojs.c3sl.ufpr.br/ ojs2/index.php/floresta/article/view/17837

DAMIANI, C.; VILAS BOAS, E. V. B.; ASQUIERI, E. R.; LAGE, M. E.; OLIVEIRA, R. A.; SILVA, F. A.; PINTO, D. M.; RODRIGUES, L.J.; SILVA, E. P.; PAULA, N. R. R. Characterization of fruits from the savanna: Araça (Psidium guinnensis Sw.) and Marolo (Annona crassiflora Mart.). Ciência e Tecnologia de Alimentos, v. 31, n. 3, p. 723-729, 2011.http://www.scielo.br/ scielo.php?pid=S010120612011000300026\&script=sci_arttext
INOUE, M. H.; SANTANA, D. C.; PEREIRA, M. J. B.; POSSAMAI, A. C. S.; AZEVEDO, V. H. Extratos aquosos de Xylopia aromatica e Annona crassiflora sobre capim-marandu (Brachiaria brizantha) e soja. Scientia Agraria, v. 10, n. 3, p. 244-250, 2009. http://ojs.c3sl.ufpr.br/ojs2/index.php/ agraria/article/view/14509

JOLY, A. B. Botânica: introdução à taxonomia vegetal. 12 ed. São Paulo SP: Companhia Editora Nacional, 1998. 777 p.

LIMA-BRITO, A.; BELLINTANI, M. C.; RIOS, A. P. S.; SILVA, J. R. S.; DORNELLES, A. L. C. Morfologia de fruto, semente e plântula de três espécies de Annona (Annonaceae). Sitientibus (série Ciências Biológicas), v. 6, n. 2, p. 119-128, 2006.

LOBÃO, A. Q.; ARAUJO, D. S. D.; KURTZ, B. C. Annonaceae das restingas do Estado do Rio de Janeiro. Rodriguesia, v. 56, n. 87, p. 85-96, 2005. http:/ rodriguesia.jbrj.gov.br/FASCICULOS/rodrig56_87/06Lobao.pdf

LORENZI, H. Árvores brasileiras: manual de identificação e cultivo de plantas arbóreas nativas do Brasil. v. 2, 2 ed. Nova Odessa: Instituto Plantarum, 2002. 382 p.

MELO, M. G. G.; MENDONÇA, M. S.; MENDES, A. M. S. Análise morfológica de sementes, germinação e plântulas de jatobá (Hymenaea intermedia Ducke var. adenotricha (Ducke) Lee \& Lang.) (Leguminosaecaesalpinioideae). Acta Amazonica, v. 34, n. 1, p. 9-14, 2004. http://www. scielo.br/pdf/aa/v34n1/v34n1a02.pdf

NEVES, C. S. V. J.; YUHARA, E. N. Caracterização dos frutos de cultivares de atemóia produzidos no norte do Paraná. Semina: Ciências Agrárias, v. 24 n. 2, p. 311-314, 2003. http://www.uel.br/revistas/uel/index.php/semagrarias/ article/view/2193/0

OLIVEIRA, A. C.; PEREIRA, M. J. B. Efeito antialimentar do extrato metanólico de Annona crassiflora Mart. sobre o percevejo marrom Euschistus heros (Fabr. 1798) (Heteroptera: Pentatomidae). Revista Brasileira de Agroecologia, v. 4, n. 2, p. 2633-2636, 2009. http://www.aba-agroecologia. org.br/ojs2/index.php/rbagroecologia/article/view/8721

OLIVEIRA, D. M. T. Morfologia comparada de plântulas e plantas jovens de leguminosas arbóreas nativas: espécies de Phaseoleae, Sophoreae, Swartzieae e Tephrosieae. Revista Brasileira de Botânica, v. 24, n. 1, p. $85-97,2001$. http://www.scielo.br/scielo.php?script=sci pdf\&pid $=$ S010084042001000100010\&lng $=$ en\&nrm=iso\&tlng $=$ pt

OMENA, M. C.; NAVARRO, D. M. A. F.; PAULA, J. E.; LUNA, J. S.; LIMA, M. R. F.; SANT'ANA, A. E. G. Larvicidal activities against Aedes aegypt of some Brazilian plants. Bioresouce Technology, v. 98, p. 2549-2556, 2007. http://www.sciencedirect.com/science/article/pii/S0960852406005049

REGO,S.S.;NOGUEIRA,A.C.;KUNIYOSHI,Y.S.;SANTOS,A.F.Caracterização morfológica do fruto, da semente e do desenvolvimento da plântula de Blepharocalyx salicifolius (H. B. K.) Berg. e Myrcengenia gertii Landrum - myrtaceae. Revista Brasileira de Sementes, v.32, n.3, p.52-60, 2010. http://www.scielo.br/scielo. php?script=sci_pdf\&pid=S010131222010000300006\&lng-pt\&nrm=iso\&tlng=pt

ROCHA FILHO, L. C.; LOMÔNACO, C. Variações fenotípicas em subpopulações de Davilla elliptica A. ST.-Hil. (Dilleniaceae) e Byrsonima intermedia A. Juss. (Malpighiaceae) em uma área de transição cerradovereda. Acta Botanica Brasilica, v. 20, n. 3, p. 719-725, 2006. http://www. scielo.br/pdf/abb/v20n3/21.pdf

SILVA, D. B.; SILVA, J. A.; JUNQUEIRA, N. T. V.; ANDRADE, L. R. M. Frutas do cerrado. Brasília: EMBRAPA, 2001. 178 p. 
SILVA, E. A. A.; MELO D. L. B.; DAVIDE, A. C.; BODE, N.; ABREU, G. B.; FARIA J. M. R.; HILHORST, H. W. M. Germination ecophysiology of Annona crassiflora seeds. Annals of Botany, v. 99, p. 823-830, 2007. http:// aob.oxfordjournals.org/content /99/5/823.full

SOUZA, V. C.; LORENZI, H. Botânica e sistemática: guia ilustrado para identificação das familias de Angiospermas da flora brasileira, baseado em APGII. Nova Odessa: Instituto Plantarum, 2005. 640 p.
TELLES, M. P. C.; VALVA, F. D.; BANDEIRA, L. F.; COELHO, A. G. Caracterização genética de populações naturais de araticunzeiro (Annona crassiflora Mart. - Annonaceae) no Estado de Goiás. Revista Brasileira de Botânica, v. 26, n. 1, p. 123-129, 2003. http://www.scielo.br/scielo.php?script=sci_pdf\&pid=S0100$84042003000100013 \& \operatorname{lng}=$ en\&nrm=iso\&tlng=pt 